\title{
Formation of organizational support of the economic security management of the engineering enterprise: methodical and practical aspects
}

\author{
Andriy Shtangret ${ }^{1 *}$, Taras Shyra ${ }^{1}$, Khrystyna Mandzinovska ${ }^{1}$ and Sofia Bilous ${ }^{2}$ \\ ${ }^{1}$ Ukrainian Academy of Printing, Faculty of Media Communications and Entrepreneurship, Pid \\ Holosko st., 19, Lviv, 79020, Ukraine \\ ${ }^{2}$ Ivan Franko National University of Lviv, Faculty of Geography, Hryshevskolo st., 4, Lviv, 79005, \\ Ukraine
}

\begin{abstract}
In the conditions of critically high uncertainty of changes in the operating environment for the most engineering enterprises, the relevance of ensuring financial security increases, not only for the effective implementation of economic activity, but also for the survival and preservation of business. The implementation of protective measures in the field of economic security provides for counteracting the negative impact of external and internal threats, and its effectiveness is determined by its ability to minimize potential losses. The development of scientific forecasts of changes in the impact of key threats is intended to form an analytical basis for adjusting tactics and strategies for managing economic security. A model for managing the economic security of a engineering enterprise has been developed that allows for the internal interaction of key elements to be carried out in advance, to concentrate the efforts of security subjects and to accumulate the necessary resources.
\end{abstract}

\section{Introduction}

In the report of the Munich Security Conference 2016, a forecast was made for the growth of challenges, threats and increased instability that the world community will face. According to the expert forecasts, the next few decades will be a period of elevated risks (including, in particular, the risk of international military confrontations), a period of fundamental transformation: the beginning of a more unstable era for the world community (Munich Security Report 2016). It can be argued that the problem of security has long historical roots, but its solutions are becoming increasingly relevant at every level, i.e., from international, national to regional, individual enterprises and individuals. So, A. Volfers consistently develops the thesis that security is a value, along with other values of

* Corresponding author: shtangret.am@ukr.net 
the national state (The Insecurity Dilemma: National, Regime and State Securities in the Third World (1992). According to D. Kaufman, (1985) who revealed the concept of security in an objective and subjective aspect, in an objective sense, security reflects the absence of threats to the basic values of society, and in the subjective aspect - the absence of fear that these values may experience destruction. J. Lazowski and O. Lange (1977) have proved the relationship between security and risk.

An important role in the study of the evolution of economic security and its international and legal aspects was played by the works of domestic and foreign scientists, such as: R. Kupiecki (2014), L. Lima (2015), N. MacFarlane (2006), S. Huntington (1996).

A visual representation of all processes in a particular enterprise is reflected, above all, in the financial sector, and therefore it is important to find and implement effective solutions for managing economic security, which should provide flexibility and adaptation to changing conditions, and at the same time make it possible to achieve financial interests.

\section{The periods of influence on the economic security of the engineering enterprise of external and internal threats}

Ensuring economic security at the national level is not possible through the implementation of operational management, but primarily due to the prediction of changes in the level of security, including due to the increased influence of a certain external or internal threat. That is, from our point of view, the main prerequisites for ensuring the economic security of engineering enterprise is the ability not only to recognize, but also to predict the change in the influence of external and internal threats, makes improvements to the system of enterprise protection as a socio-economic system. At the same time, the basic position for forecasting should be information on the current level and changes in the economic security of a certain business entity. So, practice shows (Beshelev, Gurvich, 1973) that forecasts, not at all related to past experience and the existing situation, usually do not come true. The numerous varieties of scientific predictions can be divided into three main groups:

forecasts characterizing trends and prospects for the development of a specific phenomenon for a specific time in the future. Such forecasts will be called realistic (in the future - and a variant of the situation).

forecasts characterizing the most probable state for some specific time in the future. Such a forecast will be considered pessimistic (option II).

optimistic forecasts, that is, forecasts characterizing the desired state of the phenomenon in the future (option III).

In order to improve the management of economic security of the engineering enterprise, we propose to forecast the possible change in the impact of key external and internal threats through the formation of three scenarios (realistic, pessimistic and optimistic). To further specify the methodological basis for improving the management of the economic security of the engineering enterprise, forecasts of changes in external and internal threats will be considered separately.

It should be noted that the prevailing forecasts are based on and take into account changes in the nature of each of the identified threats which occurred in two base periods: 2010-2012 and 2013-2017. (Shtangret, Mandzinovska, Kotlyarevskyi. Melnykov, 2016).

Based on the characteristics of the impact of external threats on the economic security of an engineering enterprise during the years 2018-2025, the matrix of dependence of external threats from each other is built. Below the dependencies of threats for a realistic development of the situation are given. Next, based on the dependence matrix, a directed graph is constructed, at the vertices of which there is an element $\left(q_{1}, \ldots q_{7}\right)$, whose arcs connect the vertices for which the connection is defined (Table 1). In order not to increase 
the volume of the article we omit the graph. Next, a accessibility matrix is built on the basis of the graph (Table 2).

Table 1: Matrix of dependence of external threats to economic security of engineering enterprise during 2019-2025 pp. (I scenario)

\begin{tabular}{|c|c|c|c|c|c|c|c|}
\hline$q_{i j}$ & $q_{1}$ & $q_{2}$ & $q_{3}$ & $q_{4}$ & $q_{5}$ & $q_{6}$ & $q_{7}$ \\
\hline$q_{1}$ & 0 & 1 & 0 & 0 & 0 & 0 & 1 \\
\hline$q_{2}$ & 0 & 0 & 0 & 0 & 0 & 0 & 1 \\
\hline$q_{3}$ & 1 & 1 & 0 & 0 & 0 & 0 & 0 \\
\hline$q_{4}$ & 1 & 1 & 1 & 0 & 1 & 0 & 0 \\
\hline$q_{5}$ & 0 & 1 & 1 & 0 & 0 & 0 & 0 \\
\hline$q_{6}$ & 1 & 0 & 1 & 1 & 1 & 0 & 0 \\
\hline$q_{7}$ & 0 & 0 & 0 & 0 & 0 & 0 & 0 \\
\hline
\end{tabular}

Table 2: The matrix of the reach of external threats to the economic security of a engineering enterprise during 2019-2025 pp. (I scenario)

\begin{tabular}{|c|c|c|c|c|c|c|c|}
\hline$q_{i j}$ & $q_{1}$ & $q_{2}$ & $q_{3}$ & $q_{4}$ & $q_{5}$ & $q_{6}$ & $q_{7}$ \\
\hline$q_{1}$ & 1 & 1 & 0 & 0 & 0 & 0 & 1 \\
\hline$q_{2}$ & 0 & 1 & 0 & 0 & 0 & 0 & 1 \\
\hline$q_{3}$ & 1 & 1 & 1 & 0 & 0 & 0 & 1 \\
\hline$q_{4}$ & 1 & 1 & 1 & 1 & 1 & 0 & 1 \\
\hline$q_{5}$ & 1 & 1 & 1 & 0 & 1 & 0 & 1 \\
\hline$q_{6}$ & 1 & 1 & 1 & 1 & 1 & 1 & 1 \\
\hline$q_{7}$ & 0 & 0 & 0 & 0 & 0 & 0 & 1 \\
\hline
\end{tabular}

On the basis of the matrix of reach of external threats to the economic security of a engineering enterprise (Table 2), we build an iterative table and calculate the hierarchy level of the threats identified. Calculations for options II and III are performed as described above and are further omitted.

On the basis of the calculations, we have built a Table 4, reflecting the change in the priority impact of a certain external threat on the economic security of a engineering enterprise. It is important that the proposed forecasting options (realistic, pessimistic and optimistic) make setting clear benchmarks in relation to which the situation may develop, allowing you to further specify both the amount of resources needed and the tasks for each security subject.

The results obtained (Table 3 ) show that the level of development of the national legal system and compliance with the current legislation $q_{2}$ is crucial for the economic security of a engineering enterprise in recent years (2010-2018) and for the future (I scenario). Logical (due to its significant deterioration) is also a growing influence on the development of the situation of the state of the monetary financial system of the state in 2014-2018 compared to $2010-2013$.

Compared with the above threats, it seems quite logical to stay first (2010-2013) in the middle of a rating, and then (2014-2018) at its end threats related to illegal activities, because the general unsatisfactory economic situation in the country leads to a gradual collapse of production, and this in turn, makes it possible to suggest hypothetically the existence of such a situation, when there is nothing to seize $\left(q_{4}\right)$ and spy $\left(q_{5}\right)$. 
According to the results of the analysis of the impact of internal threats in selected periods (2010-2013, 2014-2018 and 2019-2025). Three possible options were developed (by analogy with external threats) to change the impact of threats, the source of which is the internal environment of the engineering enterprise.

We omit all intermediate calculations, as a result of restrictions on the volume of a scientific article.

Table 3: Results of ranking the importance of influencing the economic security of a engineering enterprise of external threats in different periods

\begin{tabular}{|c|c|c|c|c|}
\hline \multicolumn{5}{|c|}{ Periods } \\
\hline \multirow{2}{*}{$2010-2013$} & \multirow{2}{*}{ 2014-2018 } & \multicolumn{3}{|c|}{ forecast for $2019-2025$} \\
\hline & & scenario I & scenario II & scenario III \\
\hline \multicolumn{3}{|c|}{ level of development of the legal system state $q_{2}$} & $q_{3}$ & $q_{7}$ \\
\hline$q_{3}$ & $\begin{array}{l}\text { state of the monetary } \\
\text { and financial system } \\
q_{1}\end{array}$ & \multicolumn{2}{|c|}{$q_{7}$} & $q_{2}$ \\
\hline $\begin{array}{l}\text { prerequisites raider } \\
\text { capture } q_{4}\end{array}$ & $q_{3}$ & $q_{1}$ & $q_{5}$ & $q_{3}$ \\
\hline $\begin{array}{l}\text { activity of criminal } \\
\text { structures and } \\
\text { competitors } q_{5}\end{array}$ & $q_{7}$ & $\begin{array}{c}\text { illegal } \\
\text { activities of } \\
\text { government } \\
\text { representatives } \\
q_{3}\end{array}$ & $q_{2}$ & $q_{5}$ \\
\hline $\begin{array}{l}\text { volume of domestic } \\
\text { market and increased } \\
\text { competition } q_{7}\end{array}$ & $q$ & & $q_{1}$ & $q_{4}$ \\
\hline$q_{1}$ & $q$ & & $q_{6}$ & $q_{1}$ \\
\hline interest rate & loans from commercia & anks $q_{6}$ & $q_{4}$ & $q_{6}$ \\
\hline
\end{tabular}

The data obtained for the three scenarios in the years 2019-2025 just as for the situation of recent years (2010-2018), has it own internal logic:

the value of the level and quality of expenditures $g_{6}$ (I scenario) compared to other internal threats, provided that the current problems in the economy are preserved, primarily due to the need to optimize them;

accordingly, for the deepening of economic difficulties (scenario II), the level of dependence on external sources of financing will increase $g_{7}$;

in the optimistic scenario (scenario III), the amount of proceeds from the sale of $g_{5}$, availability of working capital $g_{2}$ and profitability of the main type of activity $g_{4}$, that is, indicators determining the economic efficiency of the engineering enterprise in terms of a favorable economic environment;

the amount of revenue from the sale of $g_{5}$ (for scenarios I and II) is less important than for the desired development of events (III scenario) because, given the accumulation of problems, the amount of revenue is no longer a decisive threat to the economic security of the enterprise.

In the list of threats (for scenarios I and II) the quality and size of accounts receivable and payable $g_{1}$, availability of working capital $g_{2}$, profitability of the main activity $g_{4}$ and liquidity of assets of the enterprise $g_{3}$ remain unchanged. Such analysis results can be explained by the fact that when the situation on the market of engineering products becomes catastrophic it is difficult to talk about asset liquidity $\left(g_{3}\right)$, profitability $\left(g_{4}\right)$, working capital $\left(g_{2}\right)$ and debt $\left(g_{1}\right)$, because when enterprise is on the verge of survival, 
these indicators in spite of their importance, with favorable developments, they no longer play such a role in its negative development.

\section{Model of economic security management of the engineering enterprise}

Our analysis is based on the application of a systematic approach, because each threat that affects the course of the analyzed process is evaluated in conjunction with all the others. The system approach allows comparing possible solutions to the problem. Each problem is known to be characterized by the need to change the state, and the solution establishes how the transition will be made from the existing state to what is assumed. Predictions allow you to prepare in advance for future events, take into account their positive and negative consequences, to a certain extent regulate the course of events. Based on this, we consider it appropriate, on the basis of the prevailing predictions about the possible change in the influence of external and internal threats, to offer a scientific and methodical approach to the formation of a tactics and strategy to ensure the economic security of the enterprise (Fig. 1).

The tactical and strategic tasks that we formed in the process of implementing the economic security management of the engineering enterprise are based both on a hierarchical streamlining of external and internal threats in 2010-2018. They also based on the results of forecasting changes in the impact of threats with a realistic, optimistic and pessimistic option. Therefore, this can be considered a fairly reasonable basis for improving the management of the economic security of each engineering enterprise.

The economic security management strategy is aimed at solving a number of tasks, the implementation of which should ensure the formation of conditions for the safe development of an enterprise while meeting financial interests to the maximum, based on financial possibilities and by coordinating with the key positions the strategy of the enterprise's economic development.

\begin{tabular}{|c|c|c|c|c|c|}
\hline \multicolumn{3}{|c|}{ External threats } & \multicolumn{3}{|c|}{ Internal threats } \\
\hline \multicolumn{3}{|c|}{ Ranking the importance of influence } & \multicolumn{3}{|c|}{ Ranking the importance of influence } \\
\hline & $L$ & $\downarrow$ & & L & $\square$ \\
\hline \multicolumn{2}{|c|}{ Actual condition } & \multirow{2}{*}{$\begin{array}{l}\text { Projected } \\
\text { 2019-2025 }\end{array}$} & \multicolumn{2}{|c|}{ Actual condition } & \multirow{2}{*}{$\begin{array}{c}\text { Projected } \\
2019-2025\end{array}$} \\
\hline $2010-2013$ & $2014-2018$ & & $2010-2013$ & $2014-2018$ & \\
\hline$=1$ & L & $L$ & $\perp$ & L & $\perp L$ \\
\hline \multicolumn{6}{|c|}{ Economic Security Management of the enterprise } \\
\hline \multicolumn{3}{|c|}{ Tactical } & \multicolumn{3}{|c|}{ Strategic } \\
\hline 1 & L & 15 & 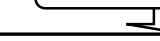 & 느 & $J L$ \\
\hline \multicolumn{3}{|c|}{$\begin{array}{l}\text { ensuring effective neutralization of threats; } \\
\text { assistance in increasing the efficiency of the economic } \\
\text { activity of the enterprise; } \\
\text { achievement of the current competitiveness of the } \\
\text { enterprise. }\end{array}$} & \multicolumn{3}{|c|}{$\begin{array}{l}\text { forecasting the impact of external and internal threats; } \\
\text { linking financial interests with the interests embodied } \\
\text { in the strategy of economic development of the } \\
\text { enterprise; } \\
\text { formation of information support for production } \\
\text { diversification. }\end{array}$} \\
\hline
\end{tabular}

Fig.1. Model of economic security management of the engineering enterprise 
Summing up, it should be emphasized that the increase in the efficiency of economic security management of domestic engineering enterprises to a large extent depends on the ability to predict changes in the level of economic security under the influence of key external and internal threats. Forecasting allows the concentration of available financial, material, labor, information and other resources to implement the most optimal tactical and strategic decisions, and provides improved management of economic security.

\section{References}

1. Munich Security Report. Boundless Crises, Reckless Spoilers, Helpless Guardians URL : https://espas.secure.europarl.europa.eu/orbis/document/munich-security-report2016-boundless-crises-reckless-spoilers-helpless-guardians (2016)

2. The Insecurity Dilemma: National, Regime and State Securities in the Third World edited by Brian. L. Job. London, Boulder : Lynne Rienner (1992)

3. Kaufman D. US National Security: A Framework for Analysis. Lexington, MA. Lexington Books (1985)

4. Łazowski J., Lange O. Wstęp do nauki o ubeypieczeniach. Optymalne decyzje / Dzieła. Tom 6. Wyd. 2. Warszawa: PWE, 204 (1977)

5. Kupiecki R. Strategia Bezpieczeństwa Narodowego RP 2014 jako instrument polityki państwa. Uwarunkowania zewnętrzne i aspekty procesowe URL: https://www.bbn.gov. $\mathrm{pl} / \mathrm{ftp} / \mathrm{dok} / 03 /$ KUPIECKI_33-2015.pdf.

6. Lima, L. WorldingBrazil: Intellectuals, Identity and Security. NY, 179. (2015).

7. MacFarlane, N. Human security and the UN: a critical history. United Nations intellectual history project (illustrated ed.). Indiana University Press. (2006)

8. Huntington S. The Clash of Civilizations and the Remaking of World Order. N. Y. : Simon \& Shuster, 368

9. Beshelev, S. D., Gurvich, F.G. Expert assessments. M.: Science, 160 (1973)

10. Shtangret, A., Mandzinovska Kh., Kotlyarevskyi. Ya., Melnykov, O. Financial security of a engineering enterprise: Methodical bases of formation and provision. Lviv: UAP, 240 (2016) 